NBER WORKING PAPER SERIES

\title{
ASSET ALLOCATION AND ASSET LOCATION: HOUSEHOLD EVIDENCE FROM THE SURVEY OF CONSUMER FINANCES
}

\author{
Daniel Bergstresser \\ James Poterba \\ Working Paper 9268 \\ http://www.nber.org/papers/w9268 \\ NATIONAL BUREAU OF ECONOMIC RESEARCH \\ 1050 Massachusetts Avenue \\ Cambridge, MA 02138 \\ October 2002
}

We are grateful to Brad Barber, David Bradford, Joel Dickson, Roger Gordon, Andrew Samwick, and John Shoven for helpful conversations, to Amir Sufi for assistance with the Survey of Consumer Finances, and to the Hoover Institution, the National Institute of Aging, and the National Science Foundation for research support. The views expressed herein are those of the authors and not necessarily those of the National Bureau of Economic Research.

(C) 2002 by Daniel Bergstresser and James Poterba. All rights reserved. Short sections of text, not to exceed two paragraphs, may be quoted without explicit permission provided that full credit, including (C) notice, is given to the source. 
Asset Allocation and Asset Location: Household Evidence from the Survey

of Consumer Finances

Daniel Bergstresser and James Poterba

NBER Working Paper No. 9268

October 2002

JEL No. H2, G2

\section{$\underline{\text { ABSTRACT }}$}

The rapid growth of assets in self-directed tax-deferred retirement accounts has generated a new set of financial decisions for many households. In addition to deciding which assets to hold, households with substantial assets in both taxable and tax-deferred accounts must decide where to hold them. This paper uses data from the Survey of Consumer Finances to assess how many households have enough assets in both taxable and tax-deferred accounts to face significant asset location choices. It also investigates the asset location decisions these households make. In 1998, 45 percent of households had at least some assets in a tax-deferred account, and more than ten million households had at least $\$ 25,000$ in both a taxable and a tax-deferred account. Many households hold equities in their tax-deferred accounts, but not in their taxable accounts, while also holding taxable bonds in their taxable accounts. Most of these households could reduce their taxes by relocating heavily-taxed fixed income assets to their tax-deferred account. Asset allocation inside and outside tax-deferred accounts is quite similar, with about seventy percent of assets in each location invested in equity securities. For nearly three quarters of the households that hold apparently tax-inefficient portfolios, a shift of less than $\$ 10,000$ in financial assets can move their portfolio to a tax-efficient allocation. Asset location decisions within IRAs appear to be sensitive to marginal tax rates; we do not find evidence for such sensitivity in other tax-deferred accounts.

Daniel Bergstresser Harvard Business School

Morgan Hall 125

Boston, MA 02163
James Poterba

Department of Economics

MIT

50 Memorial Drive

Cambridge, MA 02142

and NBER

poterba@mit.edu 
Households have always faced the asset allocation problem, having to decide which assets to purchase and how much to invest in each of them. But with the recent growth of self-directed retirement plan assets, many households now also face an asset location problem. This is the question of how much of a given asset to hold in a taxable account, and how much of it to hold in a tax-deferred account. Assets in participant-directed tax-deferred accounts totaled nearly five trillion dollars at the end of 2001, with \$2.4 trillion in Individual Retirement Accounts, and \$2.3 trillion in 401(k)-type plans. At the end of 1990 , by comparison, there were $\$ 637$ billion in IRAs, and $\$ 735$ billion in defined contribution plans.

The recent growth of IRAs, 401(k)'s, and other self-directed tax-deferred retirement vehicles has drawn substantial interest to the investment decisions made by households with these accounts. Asset location has begun to attract attention from researchers in public finance and financial economics, and it is a frequent topic of discussion among financial planners. Shoven (1998) outlined the structure of the asset location problem, and observed that tax minimization would usually dictate holding heavily-taxed taxable bonds in the tax-deferred account, with less-heavily taxed equities in the taxable account. Recent work by Dammon, Spatt, and Zhang (2002), Huang (2001), Poterba, Shoven, and Sialm (2001), and Shoven and Sialm (forthcoming) has offered further insight on the optimal asset mix for households facing various tax and financial circumstances.

Absent liquidity or other considerations, households should hold relatively heavily taxed assets in their tax-deferred account. Whether this implies that taxable bonds should be held in the tax-deferred account depends on the set of assets available to the household. For example, Shoven and Sialm (forthcoming) consider the asset location decision for investors who can only hold equities in the form of relatively tax inefficient vehicles, such as high-turnover actively-managed mutual funds. If these investors have access to tax-exempt bonds, then their optimal asset location may involve equity mutual funds in the tax-deferred account, and tax-exempt bonds in the taxable account.

Most of the recent research on asset location has focused on the derivation of tax-minimizing portfolio strategies, rather than on the analysis of household portfolio choices. Three studies have presented empirical evidence on how households actually locate their assets. The first, Bodie and Crane 
(1997), is based on a survey of TIAA-CREF participants. It finds that investors choose similar asset allocations in their taxable and tax-deferred accounts, with little apparent regard for the benefits of taxefficient asset location. One open issue concerning this research concerns the extent to which the behavior of TIAA-CREF participants can be generalized to the population at large.

A second study, Barber and Odean (forthcoming), is based on data drawn from brokerage firm records. The data suggest that households hold equity mutual funds and taxable bonds in their taxdeferred accounts, while they hold individual equities in their taxable account. Because individual equity holdings tend to be less heavily taxed than bonds or equity mutual funds, this asset location pattern is broadly consistent with tax-minimizing behavior. However, households are more likely to trade stocks in their taxable than in their tax-deferred account, even though trading in the tax-deferred account would not generate current capital gains tax liability. A key concern with this study is the degree to which data on assets held through a single brokerage firm depict a household's broader balance sheet, and in particular whether households may have offsetting positions at other financial institutions.

Finally, a third study, Amromin (2002), uses data from the Survey of Consumer Finances to investigate whether precautionary demands for financial assets, coupled with penalties and restrictions on withdrawing assets from tax-deferred accounts, can explain deviations from tax-efficient asset location patterns. The paper also provides summary information on tax-deferred account holdings. The findings suggest that the standard deviation of household labor income is related to asset location choices, with households in less risky occupations choosing more tax-efficient asset locations. This paper represents an important step toward building models of the factors that affect asset location choices.

In this paper, we also use data from several Surveys of Consumer Finances (SCFs) to analyze asset location decisions. The SCF data provide complete and disaggregate data on the portfolios held by a large sample of households. The SCF asks households to aggregate their holdings across all financial intermediaries. This makes it possible to study the overall structure of the household portfolio, rather than just the structure of one of its components. 
This paper has two goals. The first is to describe the importance of the asset location problem, as measured by the number of households facing asset location decisions and the value of the assets held by households with such choices. The second is to explore asset location patterns, and to relate these patterns to household characteristics that affect the gains from tax-efficient asset location, particularly household marginal tax rates.

The paper is divided into five sections. The first presents information on the number of households that face substantively important asset location decisions. We identify such households by the presence of significant asset holdings in both taxable and tax-deferred accounts (TDAs). Section two explores how households allocate their assets in taxable and in tax-deferred accounts. In the aggregate, equity investments make up more than two-thirds of tax-deferred financial assets and a similar proportion of taxable financial assets. The third section focuses on asset location decisions. It develops a simple classification rule to indicate whether or not households are making asset location decisions that are tax efficient. We develop several possible measures of tax efficiency, and we present estimates of the portfolio reallocation that would be needed to bring households in tax-inefficient positions to tax-efficient points. Section four presents cross-sectional regression and discrete choice evidence on the correlation between various household characteristics and asset location patterns. We investigate age, income, and net worth patterns in tax efficiency, and study how a household's marginal income tax rate affects the likelihood that its asset location choices are tax-efficient. A brief conclusion suggests directions for future research.

\section{How Many Households Face Asset Location Choices?}

The recent expansion of tax-deferred accounts has included Individual Retirement Accounts (IRAs), which are available to all taxpayers with earned income, 401(k) plans, which are employerprovided defined contribution plans available at some firms, 403(b) plans, which are similar to 401(k) plans but are available to employees at nonprofit institutions, and a number of other smaller programs. Poterba, Venti, and Wise (2001) provide more information on the growth of tax-deferred accounts and the 
characteristics of those who participate in them. Table 1 shows the total value of assets held in tax-deferred accounts as a fraction of total financial assets for selected years during the last two decades. The TDA share was 16.8 percent at the end of 2001, almost double the share in 1985 . Tax-deferred assets are roughly equally divided between IRAs and various types of defined contribution pension plan accounts. A growing fraction of the assets in IRAs were actually accumulated in pension accounts, and then "rolled over" to an IRA.

The aggregate data illustrate the growing importance of IRAs and 401(k)s, but they do not indicate how many households have substantial balances both in TDAs and in taxable accounts, and thus face substantively important asset location problems. To investigate how many households fall in this group, we use data from the 1989, 1992, 1995, and 1998 Surveys of Consumer Finances (SCFs). The SCF is the best available source of data on household wealth and its components. It asks a relatively comprehensive set of questions, has a large sample size, and oversamples high net worth households.

The 1998 SCF, which is described by Kennickell, Starr-McCluer, and Surette (2000), sampled 4309 households, with 2813 in the random sample and 1496 in the stratified random sample that over-weighted those with high incomes or net worth. By combining an area probability sample with a high-income oversample, the SCF provides accurate information on broad population characteristics, while also offering in-depth information on the households that hold a disproportionate share of financial assets and net worth. Four households are excluded from the public use dataset due to disclosure concerns, leaving a sample with 4305 observations. One fourth of the households in the survey have net worth of over a million dollars. All of our tabulations weight the various observations in the survey by their sampling weights so that our reported statistics should be representative of the U.S. population.

We measure the total value of the assets held in tax-deferred accounts as the sum of assets held in 401(k)s, 403(b)s, IRAs, and supplemental retirement accounts (SRAs). We exclude the value of assets in some traditional defined contribution plans that do not fall into these categories, since some of these plans may not allow participants much control over their asset allocation decisions. This exclusion probably leads us to understate the value of tax-deferred assets that are directly controlled by individual investors. A similar control issue arises with respect to some assets in 401(k) plans, where employer-imposed constraints on asset 
allocation may limit individual control of investment options. We nevertheless include all 401(k) plan assets, because virtually all 401(k) participants control asset allocation decisions for at least some of their holdings.

Table 2 presents summary information on the percentage of households with tax-deferred accounts. The first column shows the percentage with Individual Retirement Accounts, 401(k) plans, 403(b) plans, or other self-directed retirement saving plans. This percentage rises from 30.7 percent in 1989 to 45.7 percent in 1998. The next column shows the percentage of households with financial assets, excluding transaction accounts such as checking accounts, outside their TDA. Approximately 45 percent of the households in each of the four Surveys of Consumer Finances report ownership of these assets. This percentage would be much greater if we included financial assets in transaction accounts. We exclude them on the grounds that they do not reflect long-term investment positions in the way that TDA balances do. The last column in Table 2 shows the percentage of households with either taxable or tax-deferred assets. This group accounts for 55 percent of households in 1989 and 63 percent in 1998. These data illustrate the rapid growth during the last decade in the share of households with some involvement in financial markets.

Table 3 presents more detailed information on the set of households that face asset location problems. It shows the number of households with TDA balances, and non-TDA balances, above various threshold levels in 1989 and 1998. Asset thresholds are measured in constant 1998 dollars, and the shaded entries along the diagonal show the results when we apply the same threshold to both taxable and taxdeferred accounts. The asset thresholds do not adjust for the deferred taxes associated with holdings inside TDAs, or the greater prospective after-tax returns associated with assets held in these accounts. Poterba (2002) suggests that for time horizons of between 25 and 40 years, these two factors largely offset each other. The upper panel of Table 3 presents information from the 1989 SCF, while the lower panel presents data from 1998. The lower panel shows that in 1998, 30.3 million households had positive amounts of both taxable and tax-deferred assets. Over half of these households had significant amounts in both accounts; 15.6 million households had more than $\$ 10,000$ in both, while 10.3 million households had more than $\$ 25,000$ in both settings and 6.2 million had more than $\$ 50,000$. A smaller but still substantial group, 3.2 million 
households, had more than $\$ 100,000$ in both types of accounts. This group, which accounts for just over 3 percent of all households, held almost 42 percent of non-transaction account financial assets.

Comparing the entries in Table 3 for 1989 and 1998 demonstrates the growing importance of assets in tax-deferred accounts, and of the asset location issue. In 1989, 8.6 million households had more than $\$ 10,000$, and 2.6 million had more than $\$ 50,000$, in both taxable and tax-deferred accounts. These amounts are measured in 1998 dollars. Between 1989 and 1998, the number of households with tax-deferred assets above various thresholds grew much more rapidly than the number of households with taxable assets above various thresholds.

To place tax-deferred asset holdings in the broader context of household portfolios, Table 4 presents information on the distribution of the ratio of TDA assets to total financial assets for the 1998 SCF. Asset location issues are more important for households with large TDA balances than for those with small balances. They are relatively more important for households with roughly similar holdings inside and outside their TDAs. For a household with a portfolio almost entirely in the taxable account, the asset mix within the 401(k) may be of little consequence, since the value of the 401(k) at retirement may represent a small fraction of total wealth. For a household with almost all of its assets in the TDA, the asset location decision is also of little consequence -- there may be too few assets outside the TDA to allow much flexibility.

Table 4 shows that in 1998, the median household with both tax-deferred and taxable financial assets had 57.1 percent of its financial assets in a tax deferred account. At the 25 th percentile this value was 28 percent, while at the 75 th percentile it was 85.6 percent. Thus there is substantial dispersion in the share of assets held in TDAs, and a substantial number of households have between a quarter, and three-quarters, of their financial assets in these accounts. For higher net worth households, the distribution of tax-deferred assets relative to all financial assets shifts toward the left. The median value of this ratio for households with at least $\$ 250,000$ in net worth, for example, is 47.9 percent, compared with 57.1 percent for all households. The measure of net worth used for this cutoff includes non-financial assets, and if we limit our sample to households with financial assets of more than $\$ 250,000$, we find that the median household has only 42.3 percent of their financial assets in a TDA. These results nevertheless suggest that even in the upper strata of 
the net worth and financial asset distributions, a substantial group of households have TDA and non-TDA holdings that are of similar magnitude.

Not surprisingly, net worth is strongly correlated with TDA balances. The median net worth of households with more than $\$ 25,000$ in both taxable and tax-deferred accounts is $\$ 510,000$, while the median for those with more than $\$ 100,000$ in both settings is $\$ 1.18$ million. In both cases, mean net worth is substantially greater than median ( $\$ 1.31$ million for those with more than $\$ 25,000$ in both settings, and $\$ 2.58$ million for those with more than $\$ 100,000)$. Income also rises with TDA holdings. Median household income rises from $\$ 81,200$ for those with more than $\$ 25,000$ in both the TDA and the taxable account, to $\$ 124,900$ for those with more than $\$ 100,000$ in each setting, while the median age of the household head rises from 54 to 56. The median income statistics do not capture a significant number of retired households with large holdings of both TDA and non-TDA financial assets, but relatively low current income.

\section{Asset Allocation Patterns}

The data in the last section suggest that roughly thirty million households faced asset location decisions in 1998 , and that roughly fifteen million had at least $\$ 10,000$ in a taxable as well as a tax-deferred account. A substantial share of the households with significant TDA balances had similar balances inside and outside their TDAs. For these households, decisions about asset location can have a non-trivial impact on their long-run financial status. Consider a 45-year-old couple with $\$ 100,000$ in a TDA, and the same amount in a taxable account. Assume that the couple faces a 28 percent marginal income tax rate on interest and dividends, no capital gains tax, and that both bonds and stocks yield returns of 7 percent per year, but all of the bond income is currently taxable while only 2 percent of the equity return, the dividend yield, is taxable. If the couple allocates the TDA to stocks and the taxable account to bonds, and makes no subsequent reallocation decisions, then at age 70, net of taxes paid to withdraw assets from the TDA, they will have $\$ 732,650$. By comparison, if they invest the TDA in bonds and hold equity in their taxable account, the lower tax burden on the bond income that results from holding bonds in the TDA will result in an after-tax wealth at age 70 of $\$ 866,791$. This amounts to an 18 percent difference in wealth at retirement, a difference 
that could have important effects on financial status. In this section, we use data from the Survey of Consumer Finances to investigate asset allocation patterns, and then in the next section, we consider asset location.

\subsection{Survey of Consumer Finances Information on Asset Allocation}

For most types of tax-deferred accounts, the Survey of Consumer Finances asks whether the account is invested 'mostly or all in stock', 'split between stock and interest earning assets', or "mostly or all in interest-bearing accounts," or in "real estate," "insurance," or "other." Hardly any TDA assets are held in real estate, insurance, or "other." We use this information to construct estimates of the asset composition of taxdeferred accounts, and to compare these estimates with comparable estimates on the composition of taxable accounts. We allocate all of the assets in accounts identified as 'mostly or all in stock' to equity, half of the value of 'split' accounts, and none of the value of other accounts to equity. We then sum these equity holdings, as well as the total value of all accounts. The SCF does not distinguish taxable and tax-exempt bonds in the TDA, but based on evidence in Barber and Odean (forthcoming), we assume that there are no tax-exempt holdings.

For one group of tax-deferred accounts, the SCF collects asset values but not the composition of assets. These are the accounts of households who had a defined contribution plan at a previous job, but who have not yet rolled their account to an IRA or taken cash distributions from the plan. Nearly three hundred thousand households have such accounts. We included these households in our summary tabulations in the preceding section, but in this and later sections, we exclude them.

The SCF asks respondents to separately report the dollar values of direct stock holdings, equity mutual fund shares, and mixed equity-fixed income mutual fund shares that are held outside tax-deferred accounts. Aggregating these reported asset holdings provides a measure of equity held in taxable accounts. We do not include equity in privately-held companies, since such assets may be illiquid and difficult to transfer from the taxable to the tax-deferred account. The SCF also provides considerable detail on fixedincome assets held outside of tax-deferred accounts. Our measure of fixed-income assets includes certificates of deposit, savings bonds, and other taxable bonds held directly and through mutual funds. As in our 
foregoing analysis, we exclude the value of checking accounts and money market accounts, on the grounds that holdings of these accounts are driven by liquidity concerns rather than asset allocation or tax issues.

Tax-exempt bonds raise special problems for our analysis. While their risk attributes are similar to other fixed income securities, their income is taxed less heavily than the income from taxable bonds. The holders of tax-exempt bonds pay implicit rather than explicit taxes, so the effective tax burden on tax-exempt bonds equals the yield spread between comparably-risky taxable and tax-exempt bonds. This yield spread is usually smaller than the top marginal income tax rate times the taxable bond yield, so at least for households with relatively high marginal tax rates, tax-exempt bonds offer a higher after-tax return than taxable bonds. For some households, tax-exempt bonds may therefore offer a less risky, but lightly-taxed, alternative to taxable equity. In some of our calculations, we combine tax-exempt bonds with equity to describe household asset allocations between heavily-taxed and lightly-taxed assets.

In the $1998 \mathrm{SCF}, 4.8$ percent of all households reported owning tax-exempt bonds, and another 1.8 percent held tax-exempt money market accounts. If we restrict our attention to households that have both taxable and tax-deferred financial assets, 11.9 percent hold tax-exempt bonds. This fraction has declined; it was16.3 percent in 1989. In contrast, the percent of all households owning tax-exempt bonds has been very stable. Most of the households that own tax-exempt bonds also hold taxable fixed-income securities. In 1998, of the 4.9 million households holding tax-exempt bonds, roughly half a million reported no financial assets outside their TDA, and one million held no corporate stock.

\subsection{Asset Allocation Patterns}

Our analysis of asset location decisions focuses on whether households hold equities in their taxable accounts or in their tax-deferred accounts. Table 5 reports the first step in our analysis: summary information on the equity exposure of SCF households. The table also shows the percentage of households who hold fixed income assets, and tax-exempt bonds. The table presents cross-sectional information and it also documents recent trends. The first panel shows that equity rose from 40.4 percent of financial assets in 1989 to 69.7 percent of financial assets in 1998. This increase reflected both high returns and broadening participation in equity markets. The share of individuals holding equity in either taxable or tax-deferred 
accounts rose from 27.3 percent to 45.8 percent, while the share of investors holding fixed-income assets remained steady at around 50 percent. The share of households with any equity or fixed-income assets rose from 54 to 63 percent over this time period, while the share holding tax-exempt bonds was steady at between four and five percent.

The lower panels of Table 5 present separate information on financial assets held inside, and outside, tax-deferred accounts. In 1989, the equity share of assets held in TDAs (34 percent) was below the equity share in taxable accounts (43 percent). By 1998, 68 percent of TDA assets and 71 percent of non-TDA assets were held in equities. The similarity of the stock-bond mix inside and outside TDAs raises questions about the extent to which investors are considering tax factors in deciding whether to locate assets inside or outside the TDA. Table 5 also shows that the percentage of TDA households with equity in their TDA rose from 13.3 in 1989 to 34.5 in 1998.

Table 5 focuses exclusively on households that own equity, and it documents how these households own their stock. There can be substantial tax consequences associated with different methods of equity ownership. For example, investors who hold stock through equity mutual funds cede some control over their tax burdens to fund managers' capital gain realization decisions. The first row in Table 6 shows that in 1989, 27.3 percent of households owned stock. This total can be disaggregated: 7.3 percent held equity only through their TDA, 6 percent held equity both inside and outside the TDA, and 14 percent held equity only outside their TDA. The table also shows that 14 percent of all households $(10.2+3.8)$ had only direct equity holdings, while 6 percent $(1.1+1.1+1.8+2.0)$ held at least some equity through a mutual fund.

These summary statistics changed during the 1990s. By 1998, 12.4 percent of households held taxable equity only through stock owned directly, while 15.3 percent held some taxable equity through a mutual fund $(15.3=4.7+4.8+2.1+3.7)$. The percentage of the population holding at least some equity rose to 45.8 percent in 1998, and this was the result of rising numbers who held equity only in a TDA (from 7.3 percent to 18.1 percent) as well as both inside and outside a TDA (6 percent to 16.4 percent). The data from the Survey of Consumer Finances document a pronounced trend toward a higher fraction of equity investment being done through financial intermediaries. This trend may have implications for the effective 
tax burdens on stocks and on bonds, since the effective tax burden on equities held through intermediaries is often higher than that on buy-and-hold direct equity investments.

Table 7 presents information similar to that in Table 6, but it does so for the case of bonds rather than stocks. For bonds, the difference between holding assets within a TDA, and outside such an account, is very important for determining the effective tax burden. In addition to splitting fixed-income investments by TDA and non-TDA location, Table 7 also distinguishes taxable fixed-income investments in taxable accounts from holdings of tax-exempt bonds. Table 7 does not suggest any changes in bond ownership that are nearly as pronounced as those for stock ownership. There was literally no change between 1989 and 1998 in the percentage of households - 48.8 - owning fixed income assets. Roughly one quarter of this group held fixedincome assets inside their TDA but not outside, while nearly half held fixed income assets outside the TDA but not inside. There has been some increase, from 8.8 percent to 13.1 percent, in the percentage of households with fixed-income investments held only through their TDA, and a decline, from 25.6 to 22.7 percent, in the set of households with fixed income held only outside the TDA. The overwhelming majority of SCF households hold no tax-exempt bonds, although those who do hold these bonds tend to be in the highest net worth strata, which makes the aggregate portfolio share held in these bonds significant.

\section{Asset Location Decisions}

We now explore asset location choices in the Survey of Consumer Finances. We begin with a summary of these choices. Table 8 presents information on the number of households who report various asset location patterns in the 1998 SCF. The columns of this table indicate whether households have taxdeferred accounts, and if they do, what assets (only equity, only bonds, and some combination) they hold in these accounts. The rows describe the assets that the households hold in their taxable accounts. We combine tax-exempt bonds with equities held in taxable accounts. The table shows that there are 46.2 million households with assets in tax-deferred accounts; these are the households in columns two through four. Of this group, there are 30 million households with taxable assets outside the TDA. This is the group of households whose asset location decisions we study. The table entries for this group are shaded. 
We define tax-minimizing asset location patterns as ones that allocate fixed income assets to taxdeferred accounts before taxable accounts. Households that follow such asset location patterns are labeled as tax efficient. The entries in Table 8 that are lightly shaded correspond to asset location patterns could be taxminimizing. The darkly shaded the entries correspond to investment patterns that do not appear to be consistent with tax-minimization. There are 10.8 million households (23.4 percent of all households with TDAs, and 36 percent of those with TDAs as well as taxable assets outside the TDA) holding only fixedincome assets in their TDAs. This is a group that might be allocating their highly-taxed assets to their taxdeferred account. Less than half of this group, however, 4.1 million households, holds any equity outside the TDA. These households, who are following a strict "bonds in the TDA, stocks in the taxable account" allocation rule represent less than one tenth of the households with tax-deferred accounts, and 13.6 percent of those with both TDA and non-TDA financial assets.

Table 8 also shows that there are 2.5 million households with only bonds in the TDA, and only bonds outside the TDA. This group may also be following a tax-minimizing asset location strategy, as may be the 4.9 million households with only equity in their TDA and in their taxable account. For a household with risk tolerance that points toward holding only stocks or holding only bonds in both sets of accounts, there is no effective asset location decision. One additional group, those with bonds and stocks in the TDA, and stocks in the taxable account, could also be tax-minimizing. This group consists of 2.3 million households. Adding all of these groups in the lightly shaded boxes together, there are 13.8 million households -- 29.9 percent of all households with TDA assets, or 46 percent of those with both TDA and non-TDA financial assets -- who may be following tax-minimizing asset location rules.

Table 8 also shows that there is a substantial group of households that hold both fixed-income and equity investments, but who hold all of their equities inside their tax-deferred account. These households are in dark-shaded entries of the table. There are $6.5(=3.3+3.2)$ million households that hold only fixedincome securities outside their TDA, while holding either all equities or a mix of bonds and stocks in the TDA. These households appear to be following just the reverse of the "bonds in the TDA" strategy. Another 5.6 million households hold only equity in the TDA, while holding both bonds and equities outside the TDA. 
There are 9.7 million households that report only equity in the TDA or both equity and fixed-income securities in the TDA, and holdings of both equity and fixed-income assets outside the TDA. These households, like those who hold bonds outside the TDA and stocks in the TDA, could probably increase their after-tax financial assets at retirement by adjusting their portfolio to hold more of their fixed-income investments in their tax-deferred account, while preserving their overall risk exposure.

The entries in Table 8 use a stark criterion for inclusion in categories such as "only equity in the TDA." To capture households that have mostly equity in the TDA, we repeated the calculations that underlie the table using "greater than 80 percent of the TDA invested in equity" in place of the 100 percent cutoff in Table 8 . We made similar changes in our other categorization criteria, replacing any 100 percent cutoff with 80 percent, and 0 percent with 20 percent. The results are broadly similar to the findings in Table 8 , although fewer households are classified as following strategies that are not tax minimizing when we take this approach. Of the 46.2 million households with TDA assets, 3.8 million have more than 80 percent of their TDA in equity, and less than 20 percent of their taxable account in equity. This compares with 3.2 million households in Table 8 with all of their TDA in equity, and all of their non-TDA assets in fixed income. The number of households following asset allocation patterns that are not tax minimizing, and are dark-shaded in the table, drops from 16.2 million to 10.5 million when we use the looser categorization criterion.

Summary statistics like those in Table 8 provide a useful perspective on asset location decisions. We have also presented this information in a graphical format. Figure 1 plots the bivariate distribution of household asset allocation decisions in taxable as well as tax-deferred accounts. The concentration of households with TDA equity allocations of zero, 50 percent, and 100 percent reflects in part our procedure for turning categorical responses in the SCF into quantitative measures. The figure shows, however, that there is a very substantial concentration of households in the four corners of the distribution. There are two mass points in the distribution, corresponding to more than 80 percent equity allocation in both the TDA and outside the TDA (28.3 percent of the households with TDAs and non-TDA financial assets) and less than twenty percent equity allocation (just over 10 percent). Amromin (2002) presents similar information, although his scatter plot does not portray the high concentration of households at corner allocations. 
Figure 2 presents information similar to that in Figure 1, but households are now weighted by the total amount of financial assets that they hold inside and outside their TDAs. The data in Figures 1 and 2 taken together suggest that the households with little or no equity in their TDAs tend to be low-wealth households. When we weight by financial assets, 43.9 percent of all households have more than 80 percent of their TDA assets in equity, and a similar fraction of their non-TDA assets in equity. Figure 2 demonstrates that most of the assets in tax-deferred accounts are held in accounts with high allocations to equity, as the data in Table 5 suggested.

Table 8 and Figures 1 and 2 provide some insight on the extent to which households are pursuing tax-minimizing asset location strategies, but they do not offer a quantitative measure of how close taxinefficient households are to tax-efficient points. To address this issue, we compute the amount of wealth that each household with a TDA and non-TDA financial assets would need to reallocate in order to reach a taxefficient portfolio. Table 9 summarizes the findings. The first row reports information already presented in Table 8: there are 16.2 million households that appear to be following tax-inefficient strategies based on their current portfolio holdings. The second row asks how many of these households hold portfolios that would require asset movements of more than $\$ 2500$ to reach a tax-efficient point. For example, a household with a \$2000 TDA balance invested in equity, and large bond holdings outside the TDA, could be brought to a taxefficient point by swapping $\$ 2000$ of TDA equity for debt. Such a household would be counted as taxinefficient in the first row of Table 9, but not in the second. The results suggest that nearly half of the households with tax inefficient holdings are within $\$ 2500$ of a tax-efficient point: only 8.5 million of the 16.2 million tax-inefficient households cannot be brought to tax-efficiency with asset transfers of $\$ 2500$ or less. If we allow for asset transfers of no more than $\$ 10,000$ per household, all but 4.6 million households can be brought to the tax-efficient point. This result suggests that by moving no more than 11.8 million households $*(\$ 10,000)$, or $\$ 118$ billion, we can move three-quarters of the tax inefficient households to tax efficient points. The information in Table 9 suggests that for many of the households that are following what appear to be tax-inefficient strategies, there is only a modest difference between the amount of retirement 
wealth they would accumulate under a tax efficient strategy, and the amount they will accumulate if they continue to follow their current strategy.

Table 10 presents another calculation designed to address the proximity of existing portfolios to taxefficient allocations. It focuses on the total amount of wealth that must be reallocated to achieve a taxefficient allocation for all households with TDAs, rather than on the number of households that have holdings that are inefficient by more than a certain amount. Since asset holdings are highly concentrated, results based on households and on assets can differ substantially. The first row in Table 10 focuses on the universe of households with TDAs and positive holdings of financial assets outside the TDA. In 1998, the total balance in TDAs was \$2.64 trillion. To move all households with TDAs to a tax-minimizing asset location would require asset transfers of $\$ 250.8$ billion, or just under one tenth of TDA assets. This is slightly more than twice the transfer, calculated above, that would bring all but 4.6 million households to tax-efficient points.

Table 10 also shows the percentage of assets that need to be reallocated to achieve tax efficiency for households whose assets meet various thresholds for TDA and non-TDA holdings. For those with at least $\$ 250,000$ in both taxable and tax-deferred holdings, the required reallocation is $\$ 83$ billion, or eleven percent of TDA assets. The required reallocation as a percentage of TDA assets is smallest for those with small holdings - those who do not have at least $\$ 25,000$ in both their taxable and tax-deferred accounts. For this group, the reallocation needed to achieve tax efficiency ( $\$ 33.9$ billion) is only 4.3 percent of total TDA assets. This reflects the smaller size of TDA relative to non-TDA assets for this group, as well as a greater tendency to hold taxable fixed income assets in the TDA among small account holders.

Table 10 also shows the aggregate portfolio reallocation that would be needed to move households to equal equity/fixed-income allocations inside and outside of tax-deferred accounts. The required reallocation is not much larger than the one that is needed to move all households to the tax-minimizing asset location. The comparison of these calculations suggests that households appear to be slightly closer to the taxminimizing outcome than to a default strategy that would allocate the same fraction of both the taxable and the tax-deferred account to equities. The third column of Table 10 shows the reallocation that would be needed to move households to allocation in which fixed income assets were held first in the TDA, except that 
each household could hold $\$ 25,000$ in fixed-income assets outside of the TDA for financial emergencies. Such a buffer stock might be attractive if, as in Amromin (2002) and Huang (2001), households face random shocks to their expenditure needs and they can make early withdrawals from tax-deferred accounts only at substantial cost. The required reallocation when we allow for a buffer stock of non-TDA fixed income saving is only slightly smaller than that when we do not consider such a buffer.

The notion of a financial buffer stock outside the TDA raises an important question about the extent to which TDA and non-TDA assets are substitutes. For individuals over the age of $591 / 2$, who can withdraw assets from TDAs without penalty, the degree of substitutability is greater than for younger households who face withdrawal penalties of 10 percent. Depending on the structure of the TDA, there may also be other factors, such as hardship withdrawal restrictions in 401(k) plans, that limit the degree to which TDA assets can substitute for non-TDA assets. Our analysis focuses on the tax differences between assets held inside and outside TDAs, but non-tax differences should also be considered in future work.

\section{Explaining the Divergence Between Actual Asset Location and Tax-Minimizing Behavior}

There is substantial heterogeneity across households in the asset allocations that they chose in taxable and TDA accounts. While developing a structural model of the optimal amount of equity or debt to hold in the tax-deferred account, given the random shocks facing households, is beyond the scope of the current paper, we can explore which types of households make tax-efficient asset location decisions. We do this in three ways. First, we estimate probit models for the discrete choice of whether or not a household is in the tax efficient region in Table 8. Second, we estimate regression models to explain the difference between the share of the tax-deferred account that is held in fixed income assets, and the share of the financial asset portfolio outside the TDA that is held in fixed income assets. Finally, we estimate regression models in which the dependent variable is the share of TDA assets that would need to be reallocated to bring the household to a tax-efficient allocation.

We consider the household's marginal tax rate, its reported risk tolerance, its age, net worth, and income as explanatory variables in our analysis. All of these variables, with the exception of the marginal tax 
rate, are readily available on the Survey of Consumer Finances. Our marginal tax rate variable is an estimate of the household's marginal federal income tax rate on ordinary income, constructed using the algorithm described in Poterba and Samwick (forthcoming). The benefit of making a tax-efficient asset location decision is increasing in a household's marginal income tax rate. We therefore test for an association between the marginal tax rate and asset location patterns.

In our estimation, we report results both for the entire sample of households with TDAs and nonTDA financial assets (1709 observations), and for a subsample of those households with IRAs (1410 observations). Some households in the subsample have TDA holdings only in an IRA, while others have both IRA and non-IRA holdings. When we analyze the subsample with IRA holdings, we define our measure of tax efficiency using only the assets held in the IRA. Thus a household with an IRA fully invested in bonds, but a 401(k) with substantial equity holdings, and equity holdings in a taxable account as well would be classified as tax efficient in the subsample analysis.

Our rationale for focusing on the second group is that some households with 401(k) accounts may hold equity in their TDAs because of employer restrictions on asset allocation. Many employers make 401(k) matching contributions in employer stock, and they require employees to hold this stock for some period of time. This could result in some households holding equity in their TDA, even though they would prefer to choose a more tax-efficient asset allocation. We have no way to identify households with constrained holdings in their 401(k)s, so we focus only on IRA holdings because households have complete discretion in allocating these assets.

Table 11 presents the results of our empirical analysis of the cross-sectional determinants of asset allocation. The first two columns present estimates of probit models for a discrete dependent variable set equal to unity if the household exhibits a tax efficient asset location pattern, and zero otherwise. The basic specification is

$$
\begin{aligned}
\operatorname{Prob}\left(\mathrm{TAXEFF}_{\mathrm{i}}=1\right)= & \Phi\left(\beta+\delta^{*} \mathrm{MTR}_{\mathrm{i}}+\Sigma \alpha_{\mathrm{j}}^{*} \mathrm{AGE}_{\mathrm{ij}}+\Sigma \gamma_{\mathrm{k}} * \mathrm{NETWORTH}_{\mathrm{ik}}\right. \\
& \left.+\Sigma \eta_{\mathrm{c}}{ }^{*} \mathrm{RISK}_{\mathrm{ic}}+\Sigma \rho_{\mathrm{s}}{ }^{*} \mathrm{INCOME}_{\mathrm{is}}\right)
\end{aligned}
$$


where $\mathrm{TAXEFF}_{\mathrm{i}}$ is an indicator variable for tax efficiency, and $\Phi($.$) denotes the standard normal$ distribution function, and we include categorical indicator variables for age, net worth, and household income. The RISK variables are responses to three SCF questions that try to elicit a household's preferences with respect to the risk-reward tradeoff.

The coefficient estimates suggest a positive, although variable, relationship between household marginal tax rates and the tax efficiency of a household's asset location choices. For the full sample, the coefficient on the tax variable is positive, but statistically insignificantly different from zero. It is larger in absolute value, and statistically significantly different from zero, for the IRA subsample. The results with respect to the marginal tax rate coefficients are sensitive, however, to the other variables included in the equation. Eliminating the categorical variables for household income, for example, reduces the marginal tax rate coefficient and in some specifications results in a negative coefficient estimate.

There is some evidence of an age-related pattern in tax-efficiency. Both of the estimated equations show a substantially larger age coefficients for the 60-69 year old age group than for the 50-59 year old group. The significance of these two age categories is that the tax penalty for withdrawals from tax-deferred accounts is eliminated once the household reaches age $59 \frac{1}{2}$, thereby reducing the importance of precautionary saving considerations. Households over age 60 are more likely to have tax-efficient allocations than their slightly younger counterparts. We experimented with expanding the specification to include an interaction term between the marginal tax rate and an indicator variable for households over the age of 60 , but we could not reject the null hypothesis that the coefficient on this variable was equal to zero.

There is only weak evidence of net worth-related, or income-related, patterns in the probability of holding a tax-efficient portfolio. The specification in the first column suggests that households with net worth of less than $\$ 25,000$ are less likely to make tax-efficient choices than other households are, but the differences across net worth categories are not statistically significant. Similar problems arise in interpreting the income coefficients.

The next two columns of Table 11, columns three and four, report regression equations in which the dependent variable is DIFF, the difference between share of TDA assets in fixed-income securities and the 
share of non-TDA assets in fixed income securities. The specification includes the same explanatory variables as the probit models reported in the first two columns:

(2) $\mathrm{DIFF}_{\mathrm{i}}=\beta+\delta^{*} \mathrm{MTR}_{\mathrm{i}}+\Sigma \alpha_{\mathrm{j}}^{*} \mathrm{AGE}_{\mathrm{ij}}+\Sigma \gamma_{\mathrm{k}} * \mathrm{NETWORTH}_{\mathrm{ik}}+\Sigma \eta_{\mathrm{c}} * \mathrm{RISK}_{\mathrm{ic}}+\Sigma \rho_{\mathrm{s}} * \mathrm{INCOME}_{\mathrm{is}}+\varepsilon_{\mathrm{i}}$.

Once again, the estimated coefficient on the marginal tax rate variable is sensitive to our choice of estimation sample. The coefficients on the marginal tax rate are negative in the models for both the full sample and the IRA subsample. The coefficient is statistically significantly different from zero for the sample with IRA holdings. The point estimate for this specification, -.412, implies that a one percentage point increase in a household's marginal tax rate leads to a 0.4 percent decline in the difference between the share of fixedincome assets in the taxable and the tax-deferred account.

There is some evidence of a link between net worth and the difference in asset allocations. Higher net worth households appear to hold a higher share of their non-TDA assets in fixed income than lower net worth households. This finding is true for the IRA-only sample as well as for the broader sample. It is largely driven by a smaller amount of fixed-income holding in the tax-deferred accounts of high net worth households. There is once again some evidence of a difference in asset allocation patterns for households in their fifties and sixties, with older households showing a smaller differential between the share of fixed income assets in taxable and tax-deferred accounts. There are no pronounced patterns in the asset allocation patterns across income groups, and the coefficients on some of the adjacent indicator variables for income categories differ substantially.

The last two columns of Table 11 present our last empirical test of whether tax rates affect asset location. The dependent variable in these regression models is the percentage of TDA assets that need to be reallocated in order to reach a tax-efficient allocation. The specification is otherwise the same as that in equation (2). Once again the marginal tax rate variable has mixed effects across specifications. The coefficient estimate is positive when we estimate the model for the full sample, and negative when we estimate on the sample of IRA holders. In neither case is the coefficient on the marginal tax rate variable statistically significantly different from zero. 


\section{Conclusions}

This paper presents evidence on asset allocation and location decisions for households with substantial balances in both their taxable and tax-deferred accounts. It shows that asset location is an important financial issue for a substantial group of U.S. households. More than eleven million households in 1998 had at least $\$ 25,000$ in both taxable and tax-deferred accounts, and at least 3.4 million had more than $\$ 100,000$ invested in each type of account.

Many households have chosen asset location strategies that allocate equity to their tax-deferred account while they are holding fixed income investments in taxable account. A broad range of studies both in academic journals and in outlets that are read by financial services professionals, such as Charron (1999) and Crain and Austin (1997), suggest that households can raise their after-tax retirement wealth by holding highly taxed assets in their tax deferred account, and lightly taxed assets outside. Data from the Survey of Consumer Finances nevertheless suggest that the equity share of tax-deferred assets is roughly equal to the equity share of financial assets outside the TDA. The cost of tax inefficient behavior may be modest, however, for many households. Our calculations suggest that for roughly three quarters of the households that appear to deviate from tax-efficient asset location strategies, moving less than $\$ 10,000$ in bonds or stocks would bring them to a tax-efficient allocation. The limited size of this reallocation places an upper bound on the foregone retirement wealth associated with current asset location decisions.

We have had limited success in explaining the asset location patterns that we observe in crosssectional survey data. In the 1998 Survey of Consumer Finances, for example, we find at best a weak relationship between a household's marginal income tax rate and the tax-efficiency of its portfolio allocation. Explaining these patterns is clearly a challenge for future work, which should focus both on the information that households receive about asset allocation decisions within tax-deferred accounts, and on household awareness of the after-tax return consequences of different asset location choices.

The asset location decision is part of a broader household decision about portfolio allocation. Finding that many households pursue tax-inefficient asset location strategies raises questions about other financial decisions. We view this as a natural direction for further research, and we have begun to explore 
one such decision: consumer borrowing. Data from the 1998 SCF suggest that 44 percent of U.S. households have outstanding credit card balances. Moreover, 11.5 percent have a credit card balance of at least $\$ 5000$, and more than 18 percent have more than $\$ 2500$ in outstanding balances. Since 1986, interest payments on consumer debt have not been deductible from adjusted gross income for the purpose of computing taxable income. Interest on mortgage debt, however, remains deductible for income tax purposes. The tax deduction creates a strong incentive for households to borrow through home equity credit lines rather than on credit cards when they can. Maki (1996) and Stango (1999) suggest a decline in both credit card debt and in auto loan financing after TRA86, along with an increase in mortgage borrowing.

In spite of the tax incentives, there appear to be a significant minority of households with credit card balances who could generate substantial tax savings by increasing their use of mortgage debt. Our preliminary estimates suggest that among the 18 percent of households with at least $\$ 2500$ in outstanding consumer debt, 5.4 percent, or just under one third of the group, have at least $\$ 50,000$ in self-reported housing equity. Nearly one seventh of this group, or 2.3 percent of the aggregate population, has at least $\$ 100,000$ in housing equity. It is possible that the transactions costs associated with establishing a home equity line outweigh the tax saving for some households, particularly those who do not itemize and who do not expect to maintain their credit card balance for very long. Nevertheless, it seems that many of the same issues that arise in explaining apparently tax-inefficient asset location decisions also arise with respect to consumer borrowing decisions. Work is currently underway on these, and other related household financial decisions. 


\section{REFERENCES}

Amromin, Gene (2002), "Portfolio Allocation Choices in Taxable and Tax-Deferred Accounts: An Empirical Test of Tax Efficiency," mimeo, University of Chicago Department of Economics.

Barber, Brad M. and Terrance Odean (forthcoming), "Are Individual Investors Tax Savvy? Asset Location Evidence from Retail and Discount Brokerage Accounts." Journal of Public Economics.

Bodie, Zvi and Dwight B. Crane (1997), "Personal Investing: Advice, Theory, and Evidence," Financial Analysts Journal 53, Number 6 (November/December), 13-23.

Charron, Terry S. (1999), "Tax-Efficient Investing for Tax-Deferred and Taxable Accounts," Journal of Private Portfolio Management (Fall), 31-37.

Crain, Terry L. and Jeffrey R. Austin (1997), "An Analysis of the Tradeoff Between Tax Deferred Earnings in IRAs and Preferential Capital Gains," Financial Services Review 6 (4), 227-242.

Dammon, Robert, Chester Spatt, and Harold Zhang (2002). "Optimal Asset Location and Allocation with Taxable and Tax-Deferred Investing," Mimeo, Carnegie-Mellon University.

Huang, Jennifer (2001). "Taxable or Tax Deferred Account? Portfolio Decisions with Multiple Investment Goals." Mimeo, MIT Sloan School of Management.

Kennickell, Arthur B., Martha Starr-McCluer, and Brian Surette. 2000. "Changes in U.S. Family Finances at the End of the 1990s: Results from the 1998 Survey of Consumer Finances." Federal Reserve Bulletin (January).

Maki, Dean (1996), "Portfolio Shuffling and Tax Reform,” National Tax Journal 49, 317-329.

Poterba, James (2002). "Valuing Assets in Retirement Saving Accounts," mimeo, MIT Economics Department.

Poterba, James, John Shoven, and Clemens Sialm (2001). "Asset Location for Retirement Savers," in W. Gale, J. Shoven, and M. Warshawsky, eds., Private Pensions and Public Policies (Washington: Brookings Institution).

Poterba, James, Steven Venti, and David Wise (2001). "The Transition to Personal Accounts and Increasing Retirement Wealth: Macro and Micro Evidence," NBER Working Paper 8610.

Samwick, Andrew, and James Poterba (forthcoming). "Taxation and Household Portfolio Composition: Evidence from Tax Reforms in the 1980s and 1990s." Journal of Public Economics.

Shoven, John B. (1999). "The Location and Allocation of Assets in Pension and Conventional Savings Accounts," NBER Working Paper 7007.

Shoven, John B. and Clemens Sialm (forthcoming). "Asset Location in Tax-Deferred and Conventional Savings Accounts," Journal of Public Economics.

Stango, Victor (1999). "The Tax Reform Act of 1986 and the Composition of Consumer Debt." National Tax Journal 52, 717-739. 
Table 1: Self-Directed Tax-Deferred Assets as a Percent of Total Financial Assets

\begin{tabular}{|l|l|l|l|}
\hline Year & IRA & DC pension & Total \\
\hline 1985 & $3.1 \%$ & $5.5 \%$ & $8.6 \%$ \\
\hline 1990 & 5.3 & 6.1 & 11.4 \\
\hline 1995 & 6.9 & 7.9 & 14.8 \\
\hline 1998 & 7.9 & 8.4 & 16.3 \\
\hline 2001 & 8.5 & 8.3 & 16.8 \\
\hline
\end{tabular}

Source: Flow of Funds, Z.1 release, Tables L.10 and L.119.c. Total financial assets were $\$ 8.0$ trillion in 1985, \$12.3 trillion in 1990, \$18.6 trillion in 1995, \$27.2 trillion in 1998, and \$28.3 trillion in 2001.

Table 2: Percentage of Households with Tax-Deferred Accounts or Financial Assets Outside TaxDeferred Accounts, 1989-1998

\begin{tabular}{|l|l|l|l|}
\hline Year & Tax Deferred Assets & $\begin{array}{l}\text { Taxable Financial } \\
\text { Assets Outside TDA }\end{array}$ & $\begin{array}{l}\text { Either Taxable or Tax Deferred } \\
\text { Assets }\end{array}$ \\
\hline 1989 & 30.7 & 45.6 & 55.1 \\
\hline 1992 & 33.8 & 44.5 & 55.4 \\
\hline 1995 & 40.7 & 43.1 & 58.4 \\
\hline 1998 & $45.7 \%$ & $46.8 \%$ & $63.0 \%$ \\
\hline
\end{tabular}

Source: Tabulations from Surveys of Consumer Finances. Financial assets outside the tax-deferred account include stocks, equity mutual funds, certificates of deposit, savings bonds, and other taxable bonds. Tax-exempt bonds are not included in the set of financial assets outside the TDA. In 1989, 6.5 percent of households reported some holdings of tax-exempt bonds; this fraction was stable across surveys, rising to 6.6 percent in 1998 . Virtually all households owning tax-exempt bonds also held taxable bonds. The number of households in the four Surveys of Consumer Finances are 93 million (1989), 95.9 million (1992), 99 million (1995), and 102.6 million (1998).

Table 3: Households with Significant Holdings of Both Taxable and Tax-Deferred Financial Assets

\begin{tabular}{|l|l|l|l|l|l|}
\hline \multirow{2}{*}{$\begin{array}{l}\text { Value of Tax-Deferred } \\
\text { Account }\end{array}$} & \multicolumn{5}{l}{ Financial Assets in Taxable Account } \\
\cline { 2 - 6 } & $>0$ & $\geq 10 \mathrm{~K}$ & $\geq 25 \mathrm{~K}$ & $\geq 50 \mathrm{~K}$ & $\geq 100 \mathrm{~K}$ \\
\hline 1989 & 19.8 & 11.2 & 8.0 & 5.9 & 3.6 \\
\hline$>0$ & 13.1 & 8.7 & 6.8 & 5.1 & 3.2 \\
\hline$\geq 10 \mathrm{~K}$ & 8.0 & 5.9 & 4.8 & 3.8 & 2.4 \\
\hline$\geq 25 \mathrm{~K}$ & 4.4 & 3.6 & 2.9 & 2.6 & 1.8 \\
\hline$\geq 50 \mathrm{~K}$ & 2.0 & 1.6 & 1.4 & 1.3 & 1.0 \\
\hline$\geq 100 \mathrm{~K}$ & \multicolumn{5}{|l}{} \\
\hline 1998 & 30.3 & 18.6 & 14.0 & 10.9 & 6.6 \\
\hline$>0$ & 22.9 & 15.6 & 12.3 & 9.6 & 6.0 \\
\hline$\geq 10 \mathrm{~K}$ & 17.2 & 12.7 & 10.3 & 8.2 & 5.4 \\
\hline$\geq 25 \mathrm{~K}$ & 11.9 & 9.2 & 7.6 & 6.2 & 4.3 \\
\hline$\geq 50 \mathrm{~K}$ & 6.9 & 5.7 & 5.0 & 4.1 & 3.2 \\
\hline$\geq 100 \mathrm{~K}$ &
\end{tabular}

Notes: Each entry shows the total number of households (in millions) with the specified mix of assets in tax-deferred and taxable accounts. Asset cutoffs in both 1989 and 1998 are measured in 1998 dollars. 
Table 4: Share of Financial Assets Held in Tax Deferred Accounts, 1998

\begin{tabular}{|c|c|c|c|c|c|c|c|}
\hline \multirow[t]{3}{*}{$\begin{array}{l}\text { Net Worth or Financial } \\
\text { Asset Criterion }\end{array}$} & \multirow{3}{*}{$\begin{array}{l}\text { Millions of } \\
\text { Households with } \\
\text { TDA \& Non-TDA } \\
\text { Assets }\end{array}$} & \multicolumn{6}{|c|}{$\begin{array}{l}\text { TDA Assets as a Percentage of Total Financial Assets } \\
\text { For Households with Both TDA and Non-TDA Assets }\end{array}$} \\
\hline & & \multicolumn{5}{|c|}{ Percentile } & \multirow[t]{2}{*}{ Mean } \\
\hline & & $10^{\text {th }}$ & $25^{\text {th }}$ & Median & $75^{\text {th }}$ & $90^{\text {th }}$ & \\
\hline All Households & 30.3 & $10.6 \%$ & $28.0 \%$ & $57.1 \%$ & $85.6 \%$ & $97.3 \%$ & $55.9 \%$ \\
\hline Net Worth $\geq \$ 100 \mathrm{~K}$ & 22.6 & 9.1 & 24.8 & 54.1 & 83.4 & 96.3 & 53.8 \\
\hline Net Worth $\geq \$ 250 \mathrm{~K}$ & 14.3 & 6.8 & 19.6 & 47.9 & 77.9 & 94.5 & 48.9 \\
\hline Net Worth $\geq \$ 1 \mathrm{M}$ & 3.4 & 4.1 & 13.4 & 34.7 & 68.2 & 88.2 & 40.7 \\
\hline Financial Assets $\geq \$ 100 \mathrm{~K}$ & 15.3 & 7.3 & 20.9 & 49.2 & 79.0 & 94.7 & 49.8 \\
\hline Financial Assets $\geq \$ 250 \mathrm{~K}$ & 7.4 & 5.7 & 15.3 & 42.3 & 69.4 & 93.3 & 44.2 \\
\hline Financial Assets $\geq \$ 1 \mathrm{M}$ & 1.6 & 3.0 & 7.9 & 25.0 & 51.5 & 85.1 & 33.3 \\
\hline
\end{tabular}

Source: Authors' tabulations using 1998 Survey of Consumer Finances. See text for further details.

Table 5: Asset Allocation in Taxable and Tax-Deferred Accounts, 1989-1998

\begin{tabular}{|c|c|c|c|c|}
\hline & 1989 & 1992 & 1995 & 1998 \\
\hline \multicolumn{5}{|l|}{ All Financial Assets } \\
\hline Equity as Percentage of Total Financial Assets & $40.4 \%$ & $47.8 \%$ & $55.5 \%$ & $69.7 \%$ \\
\hline Tax Exempt Bonds as Percentage of Total Financial Assets & 13.5 & 12.0 & 9.6 & 6.2 \\
\hline Percent of Households with Equity or Fixed-Income Assets & 54.0 & 54.5 & 56.7 & 62.6 \\
\hline Percent of Households with Any Equity & 27.3 & 32.4 & 36.6 & 45.8 \\
\hline Percent of Households with Any Fixed-Income Assets & 49.2 & 48.6 & 48.4 & 50.5 \\
\hline \multicolumn{5}{|l|}{ Financial Assets Held in TDA } \\
\hline Equity as Percentage of TDA Financial Assets & 33.6 & 46.8 & 54.4 & 67.7 \\
\hline Percent of Households with Equity or Fixed-Income Assets & 29.1 & 32.2 & 38.3 & 45.0 \\
\hline Percent of Households with Any Equity & 13.3 & 19.9 & 24.7 & 34.5 \\
\hline Percent of Households with Any Fixed-Income Assets & 23.2 & 24.3 & 25.0 & 26.1 \\
\hline \multicolumn{5}{|l|}{ Financial Assets Held in Outside TDA } \\
\hline Equity as Percentage of Financial Assets in Taxable Account & 42.5 & 48.2 & 56.0 & 70.8 \\
\hline Tax Exempt Bonds as Percentage of Total Financial Assets & 17.7 & 17.6 & 14.1 & 9.4 \\
\hline Percent of Households with Equity or Fixed-Income Assets & 45.7 & 44.5 & 43.2 & 46.8 \\
\hline Percent of Households with Any Equity & 20.0 & 21.0 & 22.3 & 27.6 \\
\hline Percent of Households with Any Fixed-Income Assets & 39.9 & 38.6 & 35.7 & 35.7 \\
\hline
\end{tabular}

Source: Authors' tabulations based on Survey of Consumer Finances. Fixed income assets include holdings of tax-exempt debt. 
Table 6: Percentage of Households Holding Equity, 1989 - 1998

\begin{tabular}{|c|c|c|c|c|c|c|c|c|c|c|}
\hline \multirow[t]{2}{*}{ Year } & \multirow{2}{*}{$\begin{array}{l}\text { Any } \\
\text { Equity } \\
\text { Holdings }\end{array}$} & \multicolumn{4}{|c|}{ Equity Held Both Inside and Outside TDA } & \multirow{2}{*}{$\begin{array}{l}\text { Equity } \\
\text { Only } \\
\text { Held in } \\
\text { TDA }\end{array}$} & \multicolumn{4}{|c|}{ Equity Only Held Outside TDA } \\
\hline & & Total & $\begin{array}{l}\text { Direct and } \\
\text { Indirect }\end{array}$ & $\begin{array}{l}\text { Only } \\
\text { Indirect }\end{array}$ & Only Direct & & Total & $\begin{array}{l}\text { Direct and } \\
\text { Indirect }\end{array}$ & $\begin{array}{l}\text { Only } \\
\text { Indirect }\end{array}$ & $\begin{array}{l}\text { Only } \\
\text { Direct }\end{array}$ \\
\hline 1989 & 27.3 & 6.0 & 1.1 & 1.1 & 3.8 & 7.3 & 14.0 & 1.8 & 2.0 & 10.2 \\
\hline 1992 & 32.4 & 8.6 & 2.5 & 1.4 & 4.7 & 11.4 & 12.5 & 1.8 & 2.7 & 8.1 \\
\hline 1995 & 36.6 & 10.3 & 2.6 & 3.3 & 4.5 & 14.4 & 12.0 & 1.7 & 3.8 & 6.5 \\
\hline 1998 & $45.8 \%$ & $16.4 \%$ & $4.7 \%$ & $4.8 \%$ & $6.9 \%$ & $18.1 \%$ & $11.3 \%$ & $2.1 \%$ & $3.7 \%$ & $5.5 \%$ \\
\hline
\end{tabular}

Source: Tabulations from Surveys of Consumer Finances.

Table 7: Percentage of Households Holding Fixed-Income Assets, 1989-1998

\begin{tabular}{|c|c|c|c|c|c|c|c|c|c|c|}
\hline \multirow[t]{2}{*}{ Year } & \multirow{2}{*}{$\begin{array}{l}\text { Any } \\
\text { Fixed- } \\
\text { Income } \\
\text { Holdings }\end{array}$} & \multicolumn{4}{|c|}{ Fixed Income both Inside and Outside TDA } & \multirow{2}{*}{$\begin{array}{l}\text { Fixed- } \\
\text { Income } \\
\text { Only in } \\
\text { the TDA }\end{array}$} & \multicolumn{4}{|c|}{ Fixed Income Only Held Outside TDA } \\
\hline & & Total & $\begin{array}{l}\text { Both } \\
\text { Taxable and } \\
\text { Tax-Exempt } \\
\text { Bonds }\end{array}$ & $\begin{array}{l}\text { Only } \\
\text { Taxable } \\
\text { Bonds }\end{array}$ & $\begin{array}{l}\text { Only Tax- } \\
\text { Exempt } \\
\text { Bonds }\end{array}$ & & Total & $\begin{array}{l}\text { Both Taxable } \\
\text { and Tax- } \\
\text { Exempt } \\
\text { Bonds }\end{array}$ & $\begin{array}{l}\text { Only } \\
\text { Taxable } \\
\text { Bonds }\end{array}$ & $\begin{array}{l}\text { Only } \\
\text { Tax- } \\
\text { Exempt } \\
\text { Bonds }\end{array}$ \\
\hline 1989 & 48.8 & 14.3 & 2.3 & 11.8 & 0.3 & 8.8 & 25.6 & 1.7 & 23.6 & 0.3 \\
\hline 1992 & 48.4 & 14.5 & 1.8 & 12.4 & 0.3 & 9.8 & 24.1 & 1.9 & 21.8 & 0.5 \\
\hline 1995 & 47.6 & 13.2 & 1.6 & 11.3 & 0.3 & 11.9 & 22.6 & 2.0 & 20.0 & 0.6 \\
\hline 1998 & $48.8 \%$ & $13.0 \%$ & $1.5 \%$ & $11.1 \%$ & $0.5 \%$ & $13.1 \%$ & $22.7 \%$ & $2.2 \%$ & $19.8 \%$ & $0.7 \%$ \\
\hline
\end{tabular}

Source: Tabulations from Surveys of Consumer Finances. 
Table 8: SCF Households (millions) with Various Asset Combinations, 1998

\begin{tabular}{|l|l|l|l|l|l|}
\hline & $\begin{array}{l}\text { Households } \\
\text { with No } \\
\text { Assets in } \\
\text { TDA }\end{array}$ & $\begin{array}{l}\text { Households } \\
\text { with Only } \\
\text { Equity in their } \\
\text { TDA }\end{array}$ & $\begin{array}{l}\text { Households with } \\
\text { Both Equity and } \\
\text { Taxable Fixed } \\
\text { Income in TDA }\end{array}$ & $\begin{array}{l}\text { Households with } \\
\text { Only Taxable } \\
\text { Fixed Income in } \\
\text { TDA }\end{array}$ & $\begin{array}{l}\text { Total } \\
\text { Number of } \\
\text { Households }\end{array}$ \\
\hline All Households & \multicolumn{5}{|l|}{} \\
\hline $\begin{array}{l}\text { Households With } \\
\text { No Taxable Assets } \\
\text { Outside the TDA }\end{array}$ & 38.4 & 5.7 & 6.3 & 4.2 & 54.6 \\
\hline $\begin{array}{l}\text { Only Equity } \\
\text { Outside TDA }\end{array}$ & 4.5 & 4.9 & 2.3 & 1.3 & 13.1 \\
\hline $\begin{array}{l}\text { Equity and } \\
\text { Fixed-Income } \\
\text { Outside TDA }\end{array}$ & 3.8 & 5.6 & 4.1 & 2.8 & 16.3 \\
\hline $\begin{array}{l}\text { Only Fixed- } \\
\text { Income Outside } \\
\text { TDA }\end{array}$ & 9.7 & 3.2 & 3.3 & 2.5 & 18.7 \\
\hline Total & 56.4 & 19.4 & & 16.0 & 10.8 \\
\hline
\end{tabular}

Notes: Tax-exempt bonds are included with equity, since these bonds are lightly taxed. The results are virtually unchanged if tax-exempt bonds are aggregated with taxable fixed income securities.

Table 9: Millions of Households with Tax-Inefficient Allocations After Reallocation of Some Assets

\begin{tabular}{|c|c|c|c|c|c|}
\hline \multirow{2}{*}{$\begin{array}{l}\text { Maximum } \\
\text { Possible } \\
\text { Reallocation }\end{array}$} & \multicolumn{4}{|c|}{ Current Household Allocation Position } & \multirow{2}{*}{$\begin{array}{l}\text { Total } \\
\text { Number of } \\
\text { Households }\end{array}$} \\
\hline & $\begin{array}{l}\text { Only Equity in } \\
\text { TDA, Equity and } \\
\text { Bonds Outside }\end{array}$ & $\begin{array}{l}\text { Only Equity in } \\
\text { the TDA, Only } \\
\text { Bonds Outside }\end{array}$ & $\begin{array}{l}\text { Both Equity and } \\
\text { Bonds Inside } \\
\text { TDA and } \\
\text { Outside }\end{array}$ & $\begin{array}{l}\text { Both Equity and } \\
\text { Bonds in TDA, } \\
\text { Only Bonds Outside }\end{array}$ & \\
\hline 0 & 5.6 & 3.2 & 4.1 & 3.3 & 16.2 \\
\hline$\$ 2500$ & 3.5 & 1.4 & 2.5 & 1.1 & 8.5 \\
\hline$\$ 5000$ & 3.0 & 0.9 & 2.0 & 0.7 & 6.6 \\
\hline$\$ 10000$ & 2.3 & 0.5 & 1.4 & 0.4 & 4.6 \\
\hline
\end{tabular}

Note: Each entry indicates the number of household with a particular tax-inefficient combination of asset holdings who cannot be moved to a tax-efficient allocation with a reallocation of the amount shown in the left-most column.

Table 10: Proximity of Actual Portfolios to Tax-Minimizing Asset Location, 1998 SCF (\$1998 B)

\begin{tabular}{|l|l|l|l|l|l|}
\hline $\begin{array}{l}\text { Household } \\
\text { Characteristic }\end{array}$ & $\begin{array}{l}\text { Reallocation } \\
\text { Needed to } \\
\text { Achieve Tax } \\
\text { Efficiency }\end{array}$ & $\begin{array}{l}\text { Reallocation Need to } \\
\text { Achieve Tax Minimizing } \\
\text { Allocation, Omitting } \\
\text { \$25,000 of Fixed Income } \\
\text { Outside TDA }\end{array}$ & $\begin{array}{l}\text { Reallocation } \\
\text { Needed to Achieve } \\
\text { Equal Allocation in } \\
\text { TDA \& Taxable } \\
\text { Account }\end{array}$ & $\begin{array}{l}\text { Amount } \\
\text { of TDA } \\
\text { Assets }\end{array}$ & $\begin{array}{l}\text { Total } \\
\text { Financial } \\
\text { Assets }\end{array}$ \\
\hline $\begin{array}{l}\text { TDA and Non-TDA } \\
>0\end{array}$ & $\$ 250.8$ & $\$ 246.9$ & 266.4 & $\$ 2639.9$ & $\$ 6845.8$ \\
\hline $\begin{array}{l}\text { TDA and Non-TDA } \\
>\$ 25 \mathrm{~K}\end{array}$ & 216.9 & 208.9 & 198.3 & 1847.4 & 5500.1 \\
\hline $\begin{array}{l}\text { TDA and Non-TDA } \\
>\$ 50 \mathrm{~K}\end{array}$ & 190.2 & 174.5 & 95.7 & 1535.8 & 4631.1 \\
\hline $\begin{array}{l}\text { TDA and Non-TDA } \\
>\$ 250 \mathrm{~K}\end{array}$ & 82.8 & 77.6 & 726.4 & 2168.7 \\
\hline
\end{tabular}

Notes: Author's tabulations from the Survey of Consumer Finances. Detailed calculation methodology is described in the text. 
Table 11: Explaining Tax Efficiency and Asset Allocation Share Differences

\begin{tabular}{|c|c|c|c|c|c|c|}
\hline \multirow[t]{2}{*}{ Explanatory Variable } & \multicolumn{2}{|c|}{ Tax Efficiency Indicator } & \multicolumn{2}{|c|}{ Asset Allocation Difference } & \multicolumn{2}{|c|}{ Required Reallocation Share } \\
\hline & All TDAs & IRA Sample & All TDAs & IRA Sample & All TDAs & IRA Sample \\
\hline Marginal Tax Rate & $\begin{array}{l}0.014 \\
(0.163)\end{array}$ & $\begin{array}{l}0.414^{*} \\
(0.176)\end{array}$ & $\begin{array}{l}-0.160 \\
(0.168)\end{array}$ & $\begin{array}{l}-0.412 * \\
(0.187)\end{array}$ & $\begin{array}{l}0.027 \\
(0.090)\end{array}$ & $\begin{array}{l}-0.147 \\
(0.111)\end{array}$ \\
\hline $\begin{array}{l}\text { Will Take Substantial } \\
\text { Financial Risk }\end{array}$ & $\begin{array}{l}-0.041 \\
(0.059)\end{array}$ & $\begin{array}{l}-0.126 \\
(0.067)\end{array}$ & $\begin{array}{l}0.064 \\
(0.061)\end{array}$ & $\begin{array}{l}0.045 \\
(0.072)\end{array}$ & $\begin{array}{l}0.037 \\
(0.033)\end{array}$ & $\begin{array}{l}0.004 \\
(0.043)\end{array}$ \\
\hline $\begin{array}{l}\text { Above Average } \\
\text { Financial Risk }\end{array}$ & $\begin{array}{l}-0.063 \\
(0.042)\end{array}$ & $\begin{array}{l}-0.098 * \\
(0.049)\end{array}$ & $\begin{array}{l}-0.011 \\
(0.044)\end{array}$ & $\begin{array}{l}-0.041 \\
(0.052)\end{array}$ & $\begin{array}{l}0.017 \\
(0.024)\end{array}$ & $\begin{array}{l}0.011 \\
(0.031)\end{array}$ \\
\hline $\begin{array}{l}\text { Average Financial } \\
\text { Risk }\end{array}$ & $\begin{array}{l}-0.025 \\
(0.038)\end{array}$ & $\begin{array}{l}-0.088 * \\
(0.044)\end{array}$ & $\begin{array}{l}-0.051 \\
(0.039)\end{array}$ & $\begin{array}{l}-0.052 \\
(0.046)\end{array}$ & $\begin{array}{l}0.052^{*} \\
(0.021)\end{array}$ & $\begin{array}{l}0.054^{*} \\
(0.027)\end{array}$ \\
\hline Net Worth $0-25 \mathrm{~K}$ & $\begin{array}{l}-0.253^{*} \\
(0.080)\end{array}$ & $\begin{array}{l}-0.265^{*} \\
(0.126)\end{array}$ & $\begin{array}{l}0.038 \\
(0.104)\end{array}$ & $\begin{array}{l}0.080 \\
(0.155)\end{array}$ & $\begin{array}{l}-0.005 \\
(0.056)\end{array}$ & $\begin{array}{l}-0.015 \\
(0.092)\end{array}$ \\
\hline Net Worth $25-100 \mathrm{~K}$ & $\begin{array}{l}-0.131 \\
(0.088)\end{array}$ & $\begin{array}{l}0.002 \\
(0.122)\end{array}$ & $\begin{array}{l}-0.182 \\
(0.094)\end{array}$ & $\begin{array}{l}-0.215 \\
(0.127)\end{array}$ & $\begin{array}{l}-0.113^{*} \\
(0.050) \\
\end{array}$ & $\begin{array}{l}-0.172 * \\
(0.076)\end{array}$ \\
\hline Net Worth $100-250 \mathrm{~K}$ & $\begin{array}{l}-0.121 \\
(0.090)\end{array}$ & $\begin{array}{l}-0.053 \\
(0.121) \\
\end{array}$ & $\begin{array}{l}-0.237^{*} \\
(0.094) \\
\end{array}$ & $\begin{array}{l}-0.207 \\
(0.125)\end{array}$ & $\begin{array}{l}-0.139^{*} \\
(0.051) \\
\end{array}$ & $\begin{array}{l}-0.106 \\
(0.074) \\
\end{array}$ \\
\hline Net Worth 250K-1M & $\begin{array}{l}-0.154 \\
(0.092)\end{array}$ & $\begin{array}{l}-0.049 \\
(0.122)\end{array}$ & $\begin{array}{l}-0.344 * \\
(0.096)\end{array}$ & $\begin{array}{l}-0.344^{*} \\
(0.127)\end{array}$ & $\begin{array}{l}-0.133^{*} \\
(0.051)\end{array}$ & $\begin{array}{l}-0.130 \\
(0.075)\end{array}$ \\
\hline Net Worth $1-2.5 \mathrm{M}$ & $\begin{array}{l}-0.207^{*} \\
(0.091)\end{array}$ & $\begin{array}{l}-0.197 \\
(0.125)\end{array}$ & $\begin{array}{l}-0.360^{*} \\
(0.109)\end{array}$ & $\begin{array}{c}-0.333^{*} \\
(0.138)\end{array}$ & $\begin{array}{l}-0.093 \\
(0.059)\end{array}$ & $\begin{array}{l}-0.084 \\
(0.082)\end{array}$ \\
\hline Net Worth $>2.5 \mathrm{M}$ & $\begin{array}{l}-0.204 * \\
(0.102)\end{array}$ & $\begin{array}{l}-0.171 \\
(0.137)\end{array}$ & $\begin{array}{l}-0.352 * \\
(0.124)\end{array}$ & $\begin{array}{l}-0.345^{*} \\
(0.150)\end{array}$ & $\begin{array}{l}-0.046 \\
(0.067)\end{array}$ & $\begin{array}{l}-0.044 \\
(0.089)\end{array}$ \\
\hline Age $30-39$ & $\begin{array}{l}-0.133 * \\
(0.054)\end{array}$ & $\begin{array}{l}-0.012 \\
(0.075)\end{array}$ & $\begin{array}{l}0.177^{*} \\
(0.058)\end{array}$ & $\begin{array}{l}-0.030 \\
(0.079)\end{array}$ & $\begin{array}{l}0.040 \\
(0.031)\end{array}$ & $\begin{array}{l}-0.041 \\
(0.047)\end{array}$ \\
\hline Age 40-49 & $\begin{array}{l}-0.093 \\
(0.056)\end{array}$ & $\begin{array}{l}-0.060 \\
(0.074)\end{array}$ & $\begin{array}{l}0.203^{*} \\
(0.059)\end{array}$ & $\begin{array}{l}0.062 \\
(0.077)\end{array}$ & $\begin{array}{l}0.054 \\
(0.032)\end{array}$ & $\begin{array}{l}-0.029 \\
(0.046)\end{array}$ \\
\hline Age 50-59 & $\begin{array}{l}-0.107 \\
(0.059)\end{array}$ & $\begin{array}{l}-0.100 \\
(0.076)\end{array}$ & $\begin{array}{l}0.169^{*} \\
(0.063)\end{array}$ & $\begin{array}{l}0.080 \\
(0.081)\end{array}$ & $\begin{array}{l}0.074^{*} \\
(0.034)\end{array}$ & $\begin{array}{l}-0.001 \\
(0.048)\end{array}$ \\
\hline Age 60-69 & $\begin{array}{l}0.040 \\
(0.066)\end{array}$ & $\begin{array}{l}0.075 \\
(0.078) \\
\end{array}$ & $\begin{array}{l}0.063 \\
(0.068)\end{array}$ & $\begin{array}{l}-0.099 \\
(0.084)\end{array}$ & $\begin{array}{l}0.053 \\
(0.037)\end{array}$ & $\begin{array}{l}-0.077 \\
(0.050) \\
\end{array}$ \\
\hline Age $>70$ & $\begin{array}{l}0.003 \\
(0.071)\end{array}$ & $\begin{array}{l}-0.017 \\
(0.084)\end{array}$ & $\begin{array}{l}0.023 \\
(0.073)\end{array}$ & $\begin{array}{l}-0.128 \\
(0.088)\end{array}$ & $\begin{array}{l}0.119 * \\
(0.039)\end{array}$ & $\begin{array}{l}-0.003 \\
(0.052)\end{array}$ \\
\hline Income $25-50 \mathrm{~K}$ & $\begin{array}{l}-0.179 * \\
(0.044)\end{array}$ & $\begin{array}{l}-0.217^{*} \\
(0.049)\end{array}$ & $\begin{array}{l}0.131^{*} \\
(0.048)\end{array}$ & $\begin{array}{l}0.114^{*} \\
(0.053)\end{array}$ & $\begin{array}{l}0.043 \\
(0.026)\end{array}$ & $\begin{array}{l}0.071^{*} \\
(0.031)\end{array}$ \\
\hline Income $50-100 \mathrm{~K}$ & $\begin{array}{l}-0.189 * \\
(0.047)\end{array}$ & $\begin{array}{l}-0.227 * \\
(0.051)\end{array}$ & $\begin{array}{l}0.165^{*} \\
(0.050)\end{array}$ & $\begin{array}{l}0.129^{*} \\
(0.054)\end{array}$ & $\begin{array}{l}0.041 \\
(0.027)\end{array}$ & $\begin{array}{l}0.104^{*} \\
(0.032)\end{array}$ \\
\hline Income $100-250 \mathrm{~K}$ & $\begin{array}{l}-0.116^{*} \\
(0.058)\end{array}$ & $\begin{array}{l}-0.201 * \\
(0.063)\end{array}$ & $\begin{array}{l}0.094 \\
(0.062)\end{array}$ & $\begin{array}{l}0.139^{*} \\
(0.069)\end{array}$ & $\begin{array}{l}-0.004 \\
(0.034)\end{array}$ & $\begin{array}{l}0.052 \\
(0.041)\end{array}$ \\
\hline Income $250-500 \mathrm{~K}$ & $\begin{array}{l}-0.166^{*} \\
(0.084)\end{array}$ & $\begin{array}{l}-0.263^{*} \\
(0.085)\end{array}$ & $\begin{array}{l}0.162 \\
(0.098)\end{array}$ & $\begin{array}{l}0.134 \\
(0.104)\end{array}$ & $\begin{array}{l}-0.014 \\
(0.053)\end{array}$ & $\begin{array}{l}0.085 \\
(0.062)\end{array}$ \\
\hline Income $500 \mathrm{~K}-1 \mathrm{M}$ & $\begin{array}{l}-0.230 \\
(0.122)\end{array}$ & $\begin{array}{l}-0.312^{*} \\
(0.116)\end{array}$ & $\begin{array}{l}0.191 \\
(0.156)\end{array}$ & $\begin{array}{l}0.190 \\
(0.156)\end{array}$ & $\begin{array}{l}0.208^{*} \\
(0.084)\end{array}$ & $\begin{array}{l}0.267^{*} \\
(0.093)\end{array}$ \\
\hline Income $>1 \mathrm{M}$ & $\begin{array}{l}-0.054 \\
(0.162) \\
\end{array}$ & $\begin{array}{l}-0.044 \\
(0.163) \\
\end{array}$ & $\begin{array}{l}0.067 \\
(0.170)\end{array}$ & $\begin{array}{l}0.053 \\
(0.170) \\
\end{array}$ & $\begin{array}{l}0.007 \\
(0.092)\end{array}$ & $\begin{array}{l}0.029 \\
(0.101)\end{array}$ \\
\hline Constant & & & $\begin{array}{l}0.099 \\
(0.108)\end{array}$ & $\begin{array}{l}0.306^{*} \\
(0.147)\end{array}$ & $\begin{array}{l}0.148^{*} \\
(0.058)\end{array}$ & $\begin{array}{l}0.258^{*} \\
(0.087)\end{array}$ \\
\hline R2 & 0.0330 & 0.0366 & 0.0709 & 0.0551 & 0.0341 & 0.348 \\
\hline
\end{tabular}

Notes: Entries in columns 1 and 2 report coefficients from a probit model. The dependent variable equals unity unless the household holds fixed income assets outside a TDA, and holds some equity in a TDA. The second (third) pair of columns reports regressions with the difference between the fixed income share in the TDA and the taxable account, and the reallocation required to reach tax efficiency as a share of TDA assets, as dependent variables. The sample size for columns 1,3 , and 5 is 1709 , while for columns 2,4 , and 6 , it is 1410 . 
Figure 1. Fraction of Houscholds with Various Asset Allocations in Taxable and Tax-Deferred Accourts. 1998.

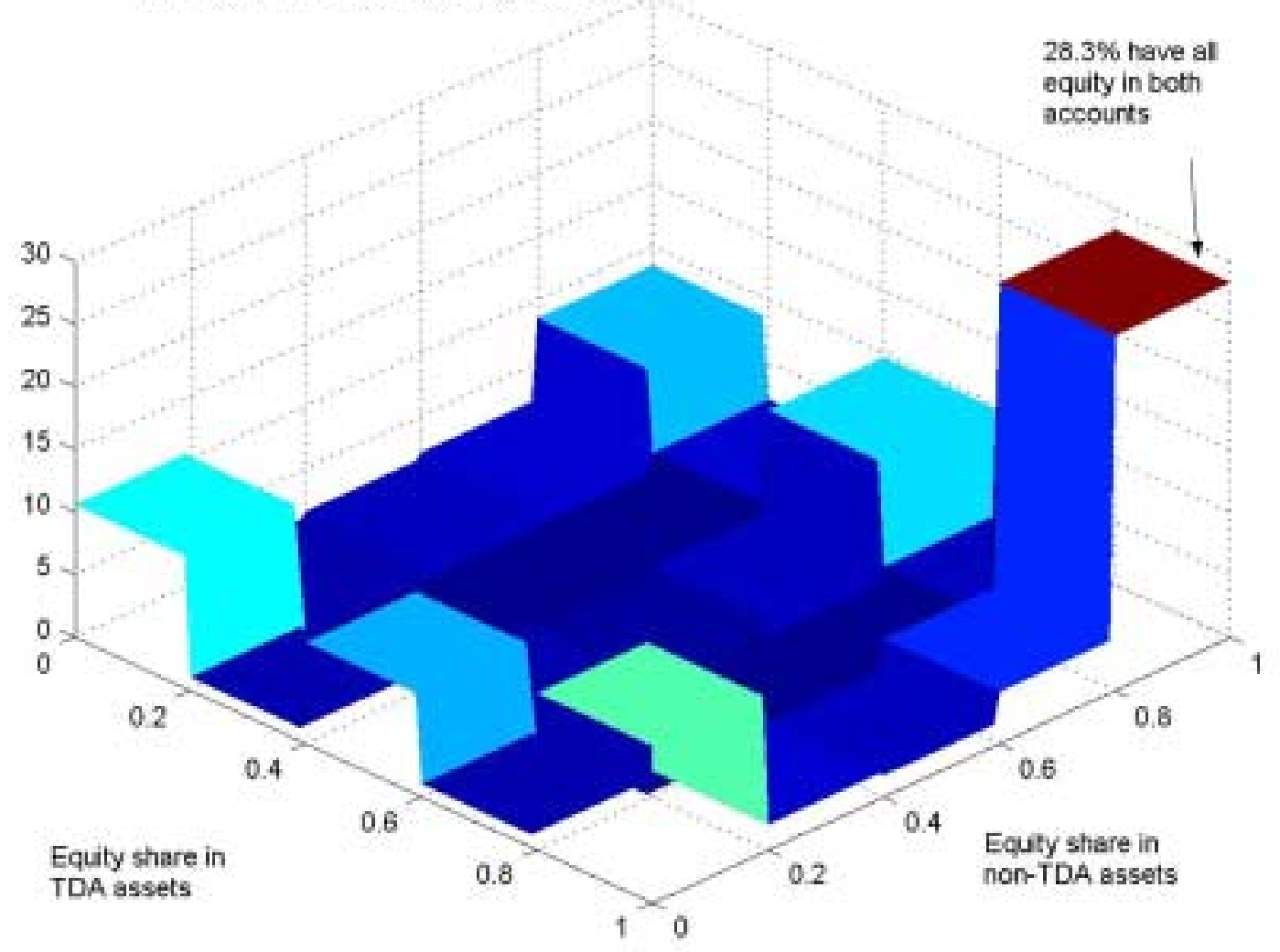


Figure 2. Fraction of Households with Various Asset Allocations in Taxable and Tax-Deferred Accounts, Weighted by Total

Financial Assets, 1998.

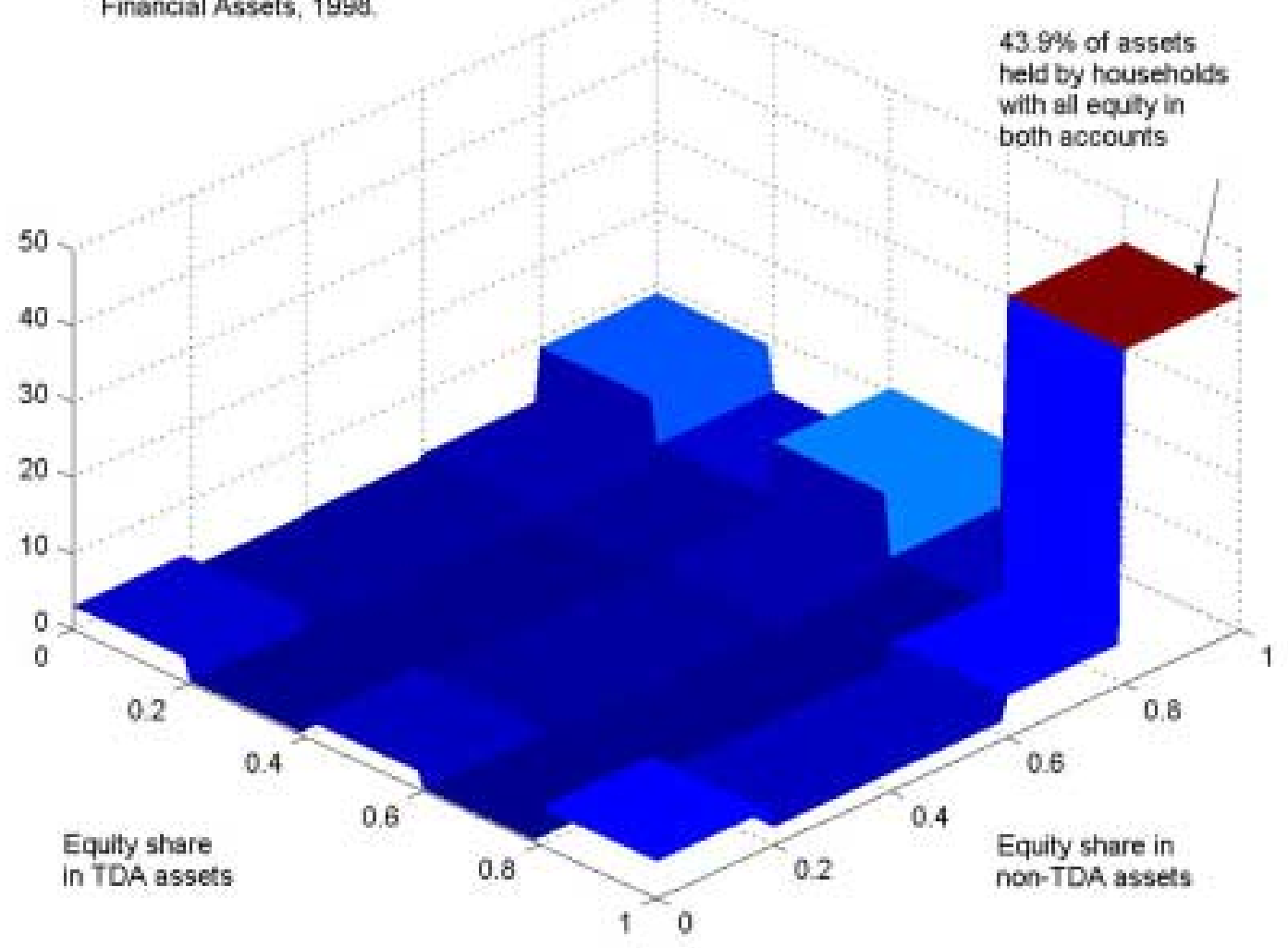

